\title{
Skeletal deformities in banded cichlid (Heros severus): clinical and radiographic diagnosis
}

\author{
H Rahmati-Holasoo $^{1^{*}}$, F Isfahani ${ }^{2}$, A rostami ${ }^{3}$, A Vajhi ${ }^{3}$, H A Ebrahimzadeh Mousavi ${ }^{1}$ and $^{\text {M Sattari }}{ }^{4}$ \\ ${ }^{1}$ Department of Aquatic Animal Health, Faculty of Veterinary Medicine, University of Tehran, Tehran, Iran \\ ${ }^{2}$ Department of Fishery, Faculty of Animal Sciences and Fishery, Sari Agricultural Sciences and Natural Re- \\ sources University, Sari, Iran \\ ${ }^{3}$ Department of Surgery and Radiology, Faculty of Veterinary Medicine, University of Tehran, Tehran, Iran \\ ${ }^{4}$ Department of Fishery, Faculty of Natural Resources, Guilan University, Somehsara, Iran
}

Recived: June 2015

\begin{abstract}
Skeletal deformities cause severe economic losses in the aquaculture industry due to the reduced market value of the affected fish. The banded cichlid (Heros severus) is an ornamental cichlid native to the Amazon region. In the summer 2011 during clinical investigation on 750 severum of 5 ornamental fish farms in Karaj and Tehran, Iran, a two-year-old severum having deformity in dorsal and anal fins was referred to the radiology section of Veterinary Teaching Hospital. Standard, high quality radiographs were taken and studied. Deformities in vertebrates, plural ribs, neural spines and hemal spines were detected. Kyphosis and Lordosis was observed in V14 to V18. The scoliosis in both parts was left and right sided and in first part was detectable in V10 to V13 and in second in V24 to V29. Neural spines of V14 to V17 and hemal spines of V16 to V22 were deformed. This case history showed that parents of this fish were offspring's of the same fish and implies that inbreeding of brood stock may cause such deformities.
\end{abstract}

Keywords: Heros severus, skeletal deformities, Kyphosis, Lordosis, scoliosis.

\section{Introduction}

The global ornamental fish trade is a rapidly grow-

Correspondence H Rahmati-Holasoo, Department of Aquatic Animal Health, Faculty of Veterinary Medicine, University of Tehran, Tehran, Iran (e-mail: rahmatih@ut.ac.ir)
Accepted: November 2015

ing industry (Winfree 1989; Noga 2010). In spite of having propagation and culture farms of ornamental fish, Iran is one of the major ornamental fish importing countries (Mehdizadeh-Mood 2009). Cichlidae are one of the most favorite families in Iran. The severum or banded cichlid, Heros severus (previously known as Cichlasoma severum), is a freshwater ornamental tropical cichlid native to the Amazon region that is kept widely in Iran. Despite of worldwide interest in ornamental fish, there are still many difficulties in culture species with high demand (Wilson, Osenberg, Mary, Watson \& Lindberg 2001). Having a good shape and the color of fish are the two important factors in ornamental fish trade. The first record of presence of skeletal deformities in fish was reported in the $16^{\text {th }}$ century (Berra \& Au 1981; Koumoundouros 2008). Since then, skeletal deformities in fish like Lower Jaw Deformity syndrome (LJD), short opercula, scoliosis, lordosis and kyphosis have been reported. The majority of skeletal deformities develop during the early life stages because of unfavorable environmental conditions and pollutants as well as due to inbreeding and mutations (Koumoundouros 2008). Skeletal deformities are among the most significant biological problems especially in ornamentals fish culture and cause severe economic losses in the aquaculture industry due to the reduced market value of the affected fish. In the culture of Atlantic salmon one of the most important causes of downgrading losses are vertebral deformities (Ornsrud, Wargelius, Saele, Pittman \& Waagbo 2004; Fjelldal, Hansen \& Berg 2007). The occurrence rate of skeletal deformities in fish is highly variable even at the same fish farm- 


\section{H Rahmati-Holasoo et al., Skeletal deformities in banded cichlid}

ing site. This can proceed to $100 \%$ and sometimes causes high mortality. In this study, we describe and illustrate the skeletal deformities found in a severum in an ornamental fish farm in Karaj, Iran.

\section{Case History}

In summer 2011 during clinical investigation of 750 banded cichlid of 5 ornamental fish farms of Karaj and Tehran, Iran, a two years old severum with deformity in dorsal and anal fins was seen in one of ornamental fish farm. Two depressions in dorsal and ventral body borders were conspicuous and anal and dorsal fins were split up into two parts (Fig. 1). But no sign of scoliosis and lordosis was detected in clinical inspections. Shape of caudal, pectoral and ventral fins was normal. The case had been kept in a $50 \mathrm{~L}$ aquarium individually and feed twice in a day with Biomar and Tubifex . Total length of the case was $123 \mathrm{~mm}$. The case had few problems in normal swimming, and the speed of swimming was lower in comparison to the normal banded cichlid but no changes in food consumption and other vital signs were detected. The case history showed that parents of this fish were offspring's of the same fish. All of the fish larvae suffered skeletal deformities and were euthanized by owner except for this severum. The other fish were with no siblings. All fish were fed by the same ration and had the same water source. This fish was referred to the radiology section of veterinary teaching hospital. Standard, high quality radiographs were taken in lateral and dorsoventral projections and radiographs were studied. The vertebral bodies were numbered from the head toward the caudal fin and the deformed vertebrae were detected.

\section{Clinical findings}

Clinical investigation of swimming behaviors showed that speed of swimming was lower than normal and turning to the left and right sides have done with difficulties. But form of swimming was horizontal and no signs of vertical swimming like head standing or head up-tail down and bottom sitting was seen. According to the case history, food

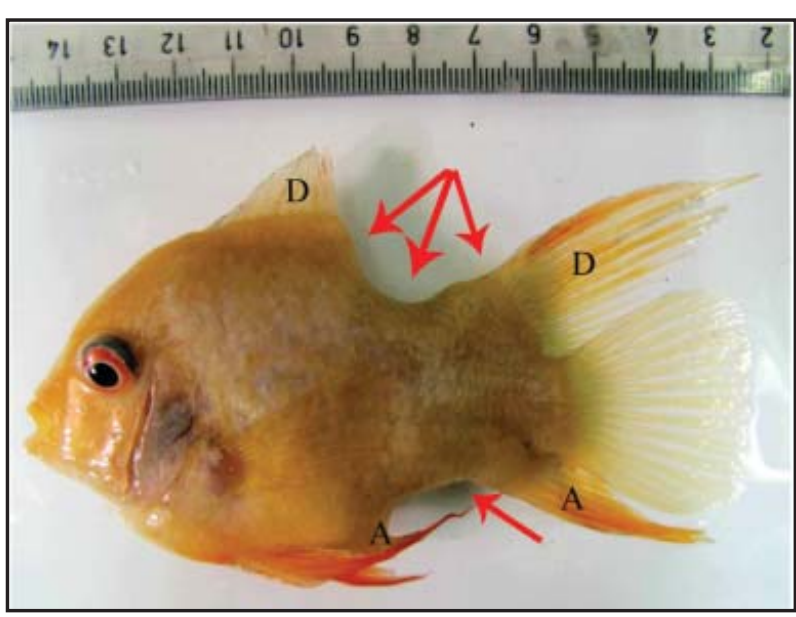

Figure $1 \mathrm{~A}$ two year old banded cichlid, with deformities in bases of dorsal and anal fins and some unformed rays of dorsal and anal fins (arrows) $(\mathrm{D}=$ dorsal fin, $\mathrm{A}=$ anal fin).

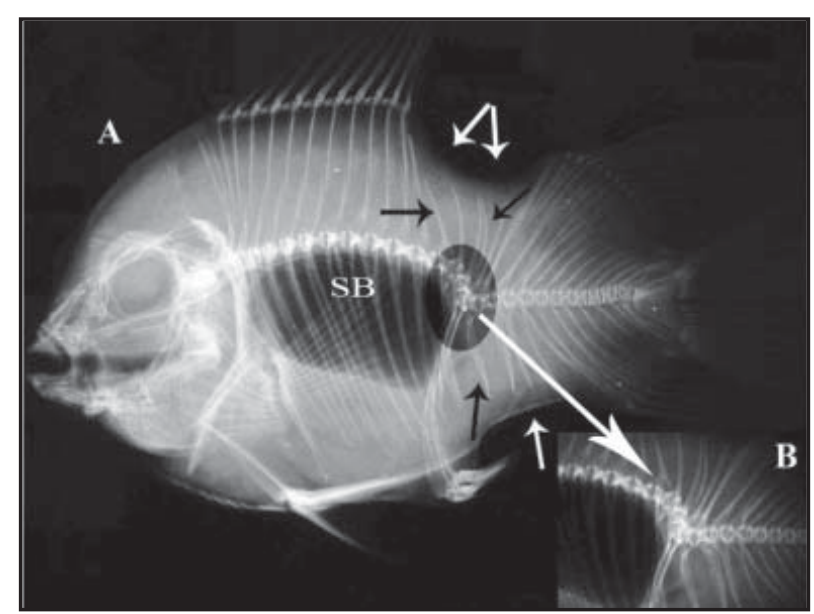

Figure 2 Lateral radiograph of banded cichlid with kyphosis and lordosis from V14 to V18 (long white arrow, A and B), deformities of neural spines of V14 to V17 and hemal spines of V16 to V22 (black arrows), and cuboid shape of swim bladder (SB), some of ptergiophores and rays of dorsal and anal fins were not formed (short white arrows).

consumption was normal but growth rate of this fish was lower compared to the normal fish. Other signs like breath rate were normal. Skeletal deformities including vertebral kyphosis, lordosis, scoliosis (in two parts), deformities of plural ribs, neural spines and hemal spines were detected in radiographs. Kyphosis and lordosis started from V14 to and continued to V18 (Fig. 2A and B). Neural spines of V14 to V17 and hemal spines of V16 to V22 had been deformed (Fig. 2A and B). Some proximal, middle, distal ptergiophores and rays of dorsal and anal fin had not been formed (Fig. 2A). Because of kyphosis and lordosis, shape of swim bladder had changed into cuboid form (Fig. 2A). The scoliosis in both 


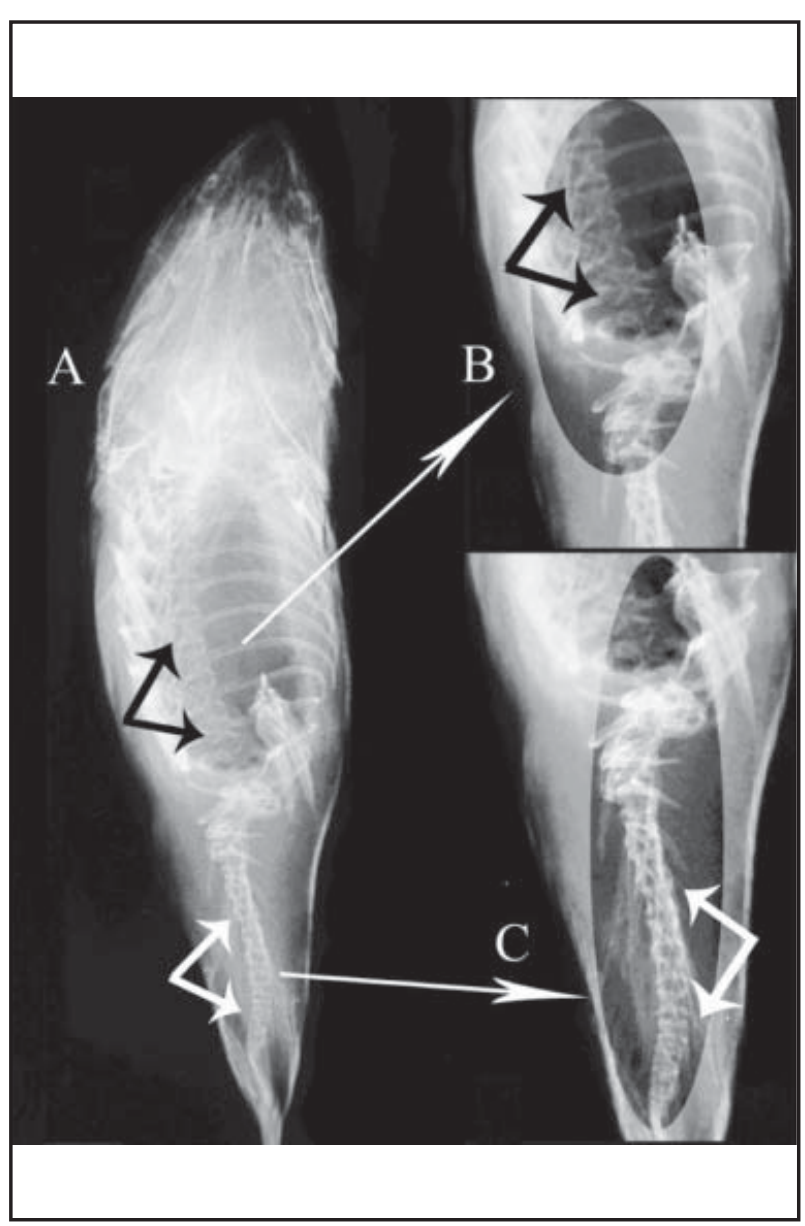

Figure 3 Dorsoventral radiograph of banded cichlid with scoliosis in two parts (A, B and C). The scoliosis is left sided from V10 to V13 (A and B, black arrows) and right sided from V24 to V29 (A and C, short white arrows).

parts was left and right sided and in first part started from V10 and continued to V13 and in second part started from V24 and continued to V29 (Fig. 3 A, B and C).

\section{Discussion}

Skeletal deformities have been often observed in the axial skeleton, jaw and operculum, fin support, and caudal bone complex. The most frequently observed axial deformities in cultured fish are lordosis, kyphosis, and scoliosis which are determined by the direction of their curvature (Lall \& Lewis-McCrea 2007; Fernandez, Pimenel, Prtiz-Delgado, Hontria, Sarasquete, Estevez, Zamboniho-Infate \& Gisbert 2009; Gavaia, Domingues, Engrola, Drake, Sarasquete, Dinis \& Cancela 2009; Alaya, Galzin R, Quignard \& Trabelsi 2011; Haga, Du, Satoh, Ko- tani, Fushimi \& Takeuchi 2011). Kyphosis and lordosis are abnormal dorsal curvature and scoliosis is abnormal lateral curvature of the vertebral column (Lim \& Lovell 1978; Chatain 1994; Koumoundouros, Maingot, Divanach \& Kentouri 2002; Kranenbarga, Waarsingb, Mullera, Weinansb \& Leeuwena 2005). Studies on skeletal deformities of fish in Iran are rare and only few reports had been mentioned. In Iran, Ebrahimzadeh Mousavi, Rostami, Rahmati-Holasoo, Masoudifard, Shafiei \& Ghadam (2011) reported scoliosis from Rutilus rutilus. In a similar study, Scoliosis in silver arowana (Osteoglossum bicirrhosum) was reported from Iran (Nouri, Moeini Jazani, Ebrahimzadeh Mousavi, Masoudifard, Golshahi, Ghasemi \& Khaji 2011). According to the authors' knowledge no reports of vertebral deformities in banded cichlid is present in Iran. Our study showed that the speed of swimming had been influenced by skeletal deformities. This result is similar to the study of Powell, Jones \& Lijalad (2009) who showed scoliotic in Atlantic salmon (Salmo salar) were significantly poorer swimmers, attaining critical swimming speeds 46 and $40 \%$ that of normal controls (Powell et al. 2009). Most of skeletal deformities of banded cichlid were found in the caudal part of the vertebral column. Similar locations have been mentioned for deformities of rainbow trout (Oncorhynchus mykiss) with compressed and fused vertebrae and for deformities of black-striped pipefish, Syngnathus abaster (Madsen \& Dalsgaard 1999; Alaya et al. 2011). Various factors such as inbreeding, environmental factors, nutritional imbalances like vitamin A, B, C, n-3 highly unsaturated fatty acid deficiencies, plus deficiencies of some minerals like phosphorus, low $\mathrm{pH}$, and exposure to heavy metals can cause skeletal deformities under culture conditions (Ferguson 1989; Gjerde et al. 2005; Lall \& Lewis-McCrea 2007; Saavedra, Barr, Pousao-Ferreira, Helland, Yufera, Dinis \& Conceicao 2009; Saavedra, Conceição, Barr, Helland, Pousão-Ferreira, Yúfera \& Dinis 2010; Haga et al. 2011). Skeletal deformities are common in cultured fish populations because of the absence of natural selection (Sadler, Pankhurst \& King 2001). The majority of skeletal deformities during the early stag- 


\section{H Rahmati-Holasoo et al., Skeletal deformities in banded cichlid}

es of life develop as a result of unfavorable environmental conditions and pollutants as well as due to inbreeding and mutations (Lemly 1993; Lemly 2002; Sfakianakis, Koumoundouros, Divanach \& Kentouri 2004; Gjerde et al. 2005; Sfakianakis, Georgakopoulou, Papadakis, Divanach, Kentouri \& Koumoundouros 2006; Koumoundouros 2008). Previous studies showed that intensive inbreeding of zebra fish, Danio rerio Hamilton cause high incidence of spontaneous skeletal deformities (Piron 1978). Also, a relationship between inbreeding and spinal deformity frequency was detected in rainbow trout and guppy, Poecilia reticulate (Aulstad \& Kittelsen 1971; Ando, Nakajima \& Fujio 1995). Although, no experiments on causes of vertebral deformities of banded cichlid was found in the literature, the case history (same ration and water source along with presence of deformity just in the siblings) and previous studies of other fish species imply that inbreeding of brood stock can cause deformities in banded cichlid (Aulstad \& Kittelsen 1971; Piron 1978; Ando et al. 1995).

In conclusion, the historical data and clinical result of this study indicated that when fish have skeletal deformities, they can live and grow but growth rate will be lower than normal rate, and they may suffer from pain. Further, severe economic losses especially in ornamental fish may occur due to such deformities. So selection of breeders is one most important parts of ornamental fish industry.

\section{References}

Alaya H.B., Galzin R., Quignard J.P. \& Trabelsi M. (2011) Spinal deformities in the black-striped pipefish Syngnathus abaster (Pisces, Syngnathidae) from the Tunis North Lake, Tunisia. Chemosphere 82, 318-320.

Ando D., Nakajima M. \& Fujio Y. (1995) Strain difference of vertebral abnormality in the guppy (Poecilia reticulate). Tohoku Journal of Agricultural Research 46, 29-34.

Aulstad D. \& Kittelsen A. (1971) Abnormal Body Curvatures of Rainbow Trout (Salmo gairdneri) Inbred Fry.
Journal of Fisheries Research Board of Canada 26, 19181920.

Berra T.M. \& Au R.J. (1981) Incidence of teratological fishes from Cedar Fork Creek, Ohio. Ohio Journal of Science 81, 225-229.

Chatain B. (1994) Abnormal swim bladder development and lordosis in sea bass (Dicentrarchus labrax) and sea bream (Sparus auratus). Aquaculture 119, 371-379.

Ebrahimzadeh Mousavi H.A., Rostami A., Rahmati-Holasoo H., Masoudifard M., Shafiei Sh. \& Ghadam M. (2011) First report of scoliosis in Rutilus rutilus caspicus from Iran: clinical and radiologic diagnosis. In: Proceedings of 3rd International Symposium of Veterinary Surgery and 9th Iranian Symposium of Veterinary Anesthesia and Radiology, Kish, Iran.

Ferguson H.W. (1989) Systemic pathology of fish. A text and atlas of comparative tissue responses in diseases of teleosts. Iowa State University Press, Ames.

Fernandez I., Pimenel M.S., Prtiz-Delgado J.B., Hontria F., Sarasquete C., Estevez A., Zamboniho-Infate J.L. \& Gisbert E. (2009) Effect of dietary vitamin A on Senegalese sole (Solea senegalensis) skeletogenesis and larval quality. Aquaculture 295, 250-265.

Fjelldal P.G., Hansen T.J. \& Berg A.E. (2007) A radiological study on the development of vertebral deformities in cultured Atlantic salmon (Salmo salar L.). Aquaculture 273, 721-728.

Gavaia P.J., Domingues S., Engrola S., Drake P., Sarasquete C., Dinis M.T. \& Cancela M.L. (2009) Comparing skeletal development of wild and hatchery-reared Senegalese sole (Solea senegalensis, Kaup 1858): evaluation in larval and postlarval stages. Aquaculture Research 40, 1585-1593.

Gjerde B., Pante M.J. \& Baeverfjord G. (2005) Genetic variation for a vertebral deformity in Atlantic salmon. Aquaculture 244, 223-236.

Haga Y., Du S.h., Satoh S.h., Kotani T., Fushimi H. \& 
Takeuchi T. (2011) Analysis of the mechanism of skeletal deformity in fish larvae using a vitamin A-induced bone deformity model. Aquaculture 315, 26-33.

Koumoundouros G., Maingot E., Divanach P. \& Kentouri M. (2002) Kyphosis in reared sea bass (Dicentrarchus labrax L.): ontogeny and effects on mortality. Aquaculture 209, 49-58.

Koumoundouros G. (2008) First record of saddleback syndrome in wild parrotfish Sparisoma cretense (L., 1758) (Perciformes, Scaridae). Journal of Fish Biology 72, 737741.

Kranenbarga S., Waarsingb J.H., Mullera M., Weinansb H. \& Leeuwena J.L. (2005) Lordotic vertebrae in sea bass (Dicentrarchus labrax L.) is adapted to increased loads. Journal of Biomechanics 38, 1239-1246.

Lall S.P. \& Lewis-McCrea L.M. (2007) Role of nutrients in skeletal metabolism and pathology in fish- an overview. Aquaculture 267, 3-19.

Lemly A.D. (1993) Teratogenic effects of selenium in natural populations of freshwater fish. Ecotoxicology and Environmental Safety 26, 181-204.

Lemly A.D. (2002) Symptoms and implications of selenium toxicity in fish: the Belews Lake case example. Aquatic Toxicology 57, 39-49.

Lim C. \& Lovell R.T. (1978) Pathology of the vitamin c deficiency syndrome in channel catfish (Ictalurus punctatus). Journal of Nutrition 108, 1137-1146.

Madsen L. \& Dalsgaard I. (1999) Vertebral column deformities in farmed rainbow trout Oncorhynchus mykiss. Aquaculture 171, 41-48.

Mehdizadeh-Mood S. (2009) Survey of infestation with ectoparasites in imported ornamental fishes. $\mathrm{PhD}$ thesis, University of Tehran, Tehran, Iran.

Noga E.J. (2010) Fish disease: diagnosis and treatment, $2^{\text {nd }}$ edn. Wiley-Blackwell.
Nouri M., Moeini Jazani M., Ebrahimzadeh Mousavi H.A., Masoudifard M., Golshahi H., Ghasemi E. \& Khaji L. (2011) Congenital Scoliosis in Silver Arowana (Osteoglossum bicirrhosum). In: Proceedings of 3rd International Symposium of Veterinary Surgery and 9th Iranian Symposium of Veterinary Anesthesia and Radiology, Kish, Iran.

Ornsrud R., Wargelius A., Saele O., Pittman K. \& Waagbo R. (2004) Influence of egg vitamin A status and egg incubation temperature on subsequent development of the early vertebral column in Atlantic salmon fry. Journal of Fish Biology 64, 399-417.

Piron R.D. (1978) Spontaneous skeletal deformities in the Zebra Danio (Brachydanio rerio) bred for fish toxicity tests. Journal of Fish Biology 13, 79-83.

Powell M.D., Jones M.A. \& Lijalad M. (2009) Effects of skeletal deformities on swimming performance and recovery from exhaustive exercise in triploid Atlantic salmon. Diseases of Aquatic Organisms 85, 59-66.

Saavedra M., Barr Y., Pousao-Ferreira P., Helland S., Yufera M., Dinis M.T. \& Conceicao L.E.C. (2009) Supplementation of tryptophan and lysine in Diplodus sargus larval diet: effects on growth and skeletal deformities. Aquaculture Research 40, 1191-1201.

Saavedra M., Conceição L.E.C., Barr Y., Helland S., Pousão-Ferreira P., Yúfera M. \& Dinis M.T. (2010) Tyrosine and phenylalanine supplementation on Diplodus sargus larvae: effect on growth and quality. Aquaculture Research 41, 1523-1532.

Sadler J., Pankhurst P.M. \& King H.R. (2001) High prevalence of skeletal deformity and reduced gill surface area in triploid Atlantic salmon (Salmo salar L.). Aquaculture 198, 369-386.

Sfakianakis D.G., Koumoundouros G., Divanach P. \& Kentouri M. (2004) Osteological development of the vertebral column and of the fins in Pagellus erythrinus (L. 1758). Temperature effect on the developmental plasticity 
and morpho-anatomical abnormalities. Aquaculture 232, 407-424.

Sfakianakis D.G., Georgakopoulou E., Papadakis I., Divanach P., Kentouri M. \& Koumoundouros G. (2006) Environmental determinants of hemal lordosis in European sea bass, Dicentrarchus labrax (Linnaeus, 1758). Aquaculture 254, 54-64.

Wilson J., Osenberg C.W., Mary C.M., Watson C.A. \& Lindberg W. (2001) Artificial reefs, the attraction-production issue, and density dependence in marine ornamental fishes. Aquarium Sciences and Conservation 3, 95-105.

Winfree R.A. (1989) Tropical fish: their production and marketing in the United States. World Aquaculture 20, 24-30. 


\section{ناهنجارى هاى اسكلتى در ماهى سورم (Heros severus): مطالعه بالينى و راديوكر افيك}

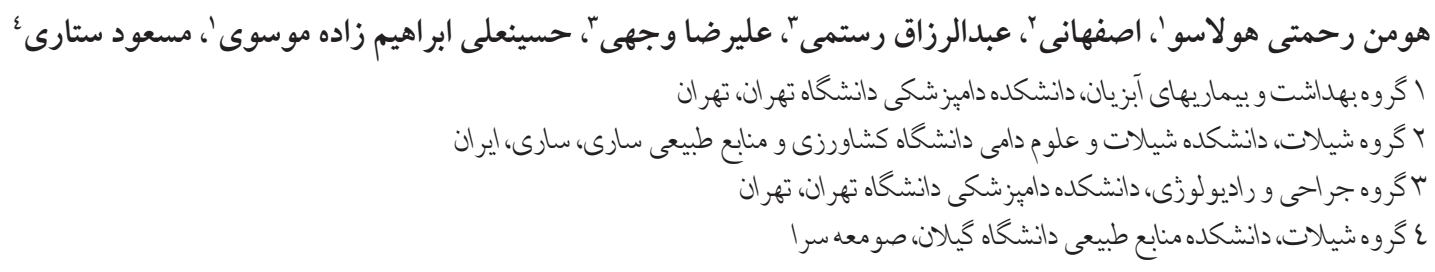

ناهنجارى هاى اسكلتى باعث زيانهاى اقتصادى شديد در صنعت آبزى يرورى به علت كاهش ارزش باز ارى ماهيان مبتلا مىشود. ماهى سورم از

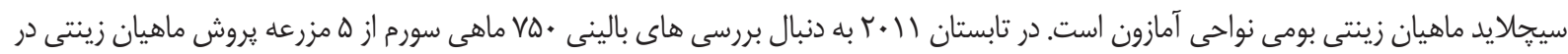

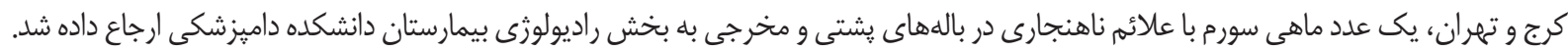

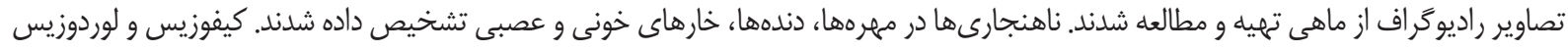

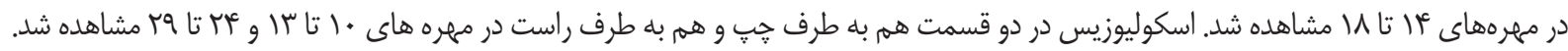

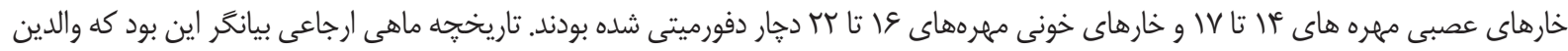

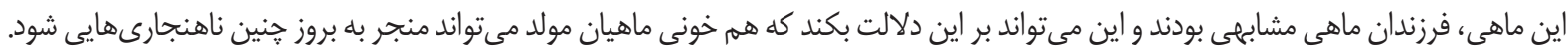

$$
\text { وازههاى كليدى: سورم، ناهنجارى هاى اسكلتى، كيفوزيس، لوردوزيس، اسكوليوزيس. }
$$

rahmatih@ut.ac.ir : نويسنده مسئول: 